\title{
A synopsis of the Hydrometra (Hemiptera, Heteroptera, Hydrometridae) from the Amazon River floodplain, Brazil, with redescription of Hydrometra argentina Berg
}

\author{
Felipe Ferraz Figueiredo Moreira ${ }^{1}$; José Ricardo Inacio Ribeiro ${ }^{2} \&$ Jorge Luiz Nessimian $^{1}$
}

\begin{abstract}
${ }^{1}$ Departamento de Zoologia, Instituto de Biologia Laboratório de Entomologia, Universidade Federal do Rio de Janeiro. Av. Brigadeiro Trompowski s/n - CCS - Bloco A, sala A1 107. 21944970 Rio de Janeiro-RJ, Brasil. Caixa-Postal: 68044. felipento@hotmail.com; nessimia@acd.ufrj.br. ${ }^{2}$ Centro de Ciências Rurais de São Gabriel. Universidade Federal do Pampa, Av. Antônio Trilha, 1847, Centro. 97300-000 São Gabriel-RS, Brasil. joseribeiro@unipampa.edu.br
\end{abstract}

\begin{abstract}
A synopsis of the Hydrometra (Hemiptera, Heteroptera, Hydrometridae) from the Amazon River floodplain, Brazil, with redescription of Hydrometra argentina Berg. Hydrometra argentina Berg, 1879, H. caraiba Guérin-Méneville, 1857 and H. guianana Hungerford \& Evans, 1934 are newly recorded in the Amazon River floodplain, Brazil. A redescription of $H$. argentina is also given, as the original description is incomplete. A key to the three known species occurring in this region is provided. Hydrometra argentina can be distinguished from H. caraiba and H. guianana by the body length smaller than $12.50 \mathrm{~mm}$, anteoculus/postoculus ratio between 1.80 and 2.00 , clypeus narrow and conical, metacetabulum with no circular pits, and projections on male abdominal sternite VI in the shape of simple spines. The other species can be distinguished mainly by the anteoculus/postoculus ratio and position of projections on male abdominal sternite VI.
\end{abstract}

KEYWORDS. Amazon; aquatic insects; Gerromorpha; Neotropics; taxonomy.

\begin{abstract}
RESUMO. Sinopse de Hydrometra (Hemiptera, Heteroptera, Hydrometridae) da várzea do Rio Amazonas, Brasil, com a redescrição de Hydrometra argentina Berg. Novos registros na várzea do Rio Amazonas, Brasil, são feitos para Hydrometra argentina Berg, 1879, H. caraiba Guérin-Méneville, 1857 e H. guianana Hungerford \& Evans, 1934. Uma redescrição de $H$. argentina também é provida, já que a descrição original é incompleta. Uma chave de identificação para as três espécies do gênero ocorrentes na área é apresentada. Hydrometra argentina pode ser distinguida de $H$. caraiba e $H$. guianana pelo comprimento do corpo menor que $12,50 \mathrm{~mm}$, proporção anteóculo/pós-óculo entre 1,80 e 2,00, clípeo estreito e cônico, metacetábulo sem pontuações, e projeções do esternito abdominal VI do macho na forma de espinhos simples. As demais espécies distinguem-se principalmente pela proporção anteóculo/pós-óculo e pela posição das projeções do esternito abdominal VI do macho.
\end{abstract}

PALAVRAS-CHAVE. Amazônia; Gerromorpha; insetos aquáticos; Região Neotropical; taxonomia.

The Amazon River floodplain is one of the most important Amazonian ecosystems in terms of biodiversity and productivity, occupying an area of more than $100.000 \mathrm{~km}^{2}$, including small tributaries, open water lakes, floating meadows and a great extension of seasonally flooded forests. Within the aquatic insect fauna in floodplains, several aquatic heteropteran species are present, but there is scarce knowledge on their distribution (Goulding et al. 2003; Nessimian et al. 2004).

Hydrometridae is a group of moderate sized bugs generally found associated with the marginal vegetation of calm water collections, although some genera may have terrestrial or semiterrestrial representatives. Among the semi-aquatic genera, only Hydrometra (37 known neotropical species, 4 in Brazilian Amazon) has previews records on the Amazon River floodplain. (Hungerford \& Evans 1934; Nieser 1970; Polhemus \& Polhemus 2008).

In the present paper we make a survey of the Hydrometra found on the Amazon River floodplain, also presenting new records in Brazil, a key to the represented species and the redescription of $H$. argentina Berg, 1879, as the original description is deficient.

\section{MATERIALAND METHODS}

The study area included twenty six localities in the floodplain of the Amazon River in Brazilian territory, between the municipalities of Tabatinga, Amazonas State, and Afuá, Pará State. Examined material was collected associated with floating plants of the genus Eichhornia or on U.V. light traps positioned near to the water.

Deposition of the specimens was made on the entomological collections of the Instituto Nacional de Pesquisas da Amazônia (INPA) and the Coleção Entomológica Professor José Alfredo Pinheiro Dutra, Departamento de Zoologia, Instituto de Biologia, UFRJ, Rio de Janeiro, Brazil (DZRJ). Additional material from INPA, DZRJ and Museu Nacional do Rio de Janeiro (MNRJ) was observed, and new records from other localitites in Brazil are presented in the distribution section bellow each species.

Identification of specimens was based mainly on Hungerford \& Evans (1934) and Nieser (1970). Nomenclature of structures and measurements (partially) follow Hungerford \& Evans (1934) and Andersen (1977). Measurements are given in millimeters. 
In quotations of label data, a comma separates different information, a period mark separates information on different specimens, and a semicolon separates different specimens with same information. New locality records are marked with an exclamation period. All the localities are organized by north to south order. Names of collectors or deposition institutes appear inside parenthesis.

\section{RESULTS ANDDISCUSSION}

Three species of Hydrometra were recorded in the study area: $H$. argentina; $H$. caraiba Guérin-Méneville, 1857 , and $H$. guianana Hungerford \& Evans, 1934.

\section{Identification key to the species of Hydrometra recorded on the floodplain of the Amazon River}

1. Body length at most $12.5 \mathrm{~mm}$; anteoculus/postoculus ratio between 1.80 and 2.00; clypeus narrow and conical (Fig.1: CLY); rostrum distinctly surpassing eyes; pro- and mesoacetabulum with at most two circular pits each; metacetabulum with no circular pits; projections on male abdominal sternite VI in the shape of simple spines (Fig. 5: PRJ) ..... Hydrometra argentina

1. Body length at least $14.00 \mathrm{~mm}$; anteoculus/postoculus ratio at least 2.50; clypeus broad, not conical (Fig. 7, 9); rostrum not surpassing eyes; pro- and mesoacetabulum with more than ten circular pits each; metacetabulum with circular pits; projections on male abdominal sternite VI are brushes of setae (Fig. 8, 10: PRJ)

... 2

$2 \mathrm{a}(1 \mathrm{~b})$. Clypeus with a small angulose median projection (Fig. 9); propleura with seven to eight circular pits in a line; projections of abdominal sternite VI of male located on the posterior half of the segment (Fig. 10: PRJ) ....

Hydrometra guianana

2b. Clypeus with a short blunt median projection (Fig. 7); propleura with nine to twelve circular pits in two lines, most dorsal one shorter; projections of abdominal sternite VI of male located on the middle of the segment (Fig. 10: PRJ) Hydrometra caraiba

\section{Hydrometra argentina Berg, 1879}

Hydrometra mensor White, 1879 non H. mensor Champion, 1898 [synonym determined by Drake (1954)]

Limnometra chilensis Reed, 1901 [synonym determined by Drake (1953)]

Hydrometra kirkaldyana Torre-Bueno, 1926 [synonym determined by Drake (1953)]

Hydrometra husseyi Torre-Bueno, 1926 [synonym determined by Drake (1953)]

Examined material. BRAZIL: Amapá - Oiapoque, 15.V.1989, (Alvarenga): 1 macropterous female (MNRJ). Pará - Prainha, Retiro JK, 04.X.2003, (P. de Marco \& N. Ferreira-Jr.): 1 macropterous female (DZRJ). Amazonas - Urucará, Lírio do Vale, 24.IX.2003: 14 macropterous males and 5 macropterous males (INPA) [Albano Lake, UV light trap, $-2,41418^{\circ}-57,49993^{\circ}$. Itacoatiara, Ilha da Trindade, 22.IX.2003: 2 macropterous females and 1 macropterous male (INPA) [lake, UV light trap, $-3,31345^{\circ} /-58,73231^{\circ}$ ]. Nossa Senhora do Perpétuo Socorro, 21.IX.2003: 15 macropterous males and 8 macropterous females (DZRJ) [Traíra Lake, UV light trap, $-3,159975^{\circ}$ $-59,32716^{\circ}$ ]. Bahia - Juazeiro, V.1974, (J. C. M. Carvalho): 1 macropterous female (MNRJ). Rio de Janeiro - Macaé, 2005, (N Ferreira-Jr.): 1 apterous female (DZRJ). Maricá, 26.I.????, (no collector information): 1 apterous female (DZRJ) [Ubatiba River]. Rio de Janeiro, Ilha do Fundão, 9.VI.2000, (A. L. Carvalho): 1 macropterous female (DZRJ) [pool]. Mangaratiba, Ilha da Marambaia, I.1953, (Castro): 1 brachypterous female (DZRJ). São Paulo - Ubatuba, Parque Estadual da Serra do Mar, Núcleo Picinguaba, 19.VI.2004, (F. F. F. Moreira): 1 apterous female (DZRJ) [pond].

Redescription. Macropterous male. Body length -9.60 10.40; body width on pronotum $-0.39-0.51$; head length2.72-2.91; head width across eyes-0.35-0.41; anteoculus/ postoculus ratio-1.87-2.00; antennal joints length (intersegmental pieces not included): I-0.39-0.41, II -0.84 0.95, III-1.92-2.08, IV-0.96-1.01; minimum interocular distance -0.13 ; eye width $-0.12-0.14$; rostrum length beyond eyes - $0.29-0.38$; pronotum length on midline $-1.35-1.42$; wing length $-4.00-4.65$; forecoxa/midcoxa distance- $-0.78-0.83$; midcoxa/hindcoxa distance-1.25-1.38; foreleg length: femur-2.24-2.43, tibia-2.27-2.56, tarsomerus I-0.06, tarsomerus II $-0.19-0.38$, tarsomerus III $-0.16-0.23$; midleg length: femur $-2.62-2.98$, tibia $-2.94-3.10$, tarsomerus I$0.06-0.09$, tarsomerus II $-0.28-0.38$, tarsomerus III $-0.18-0.24$; hindleg length: femur $-3.30-3.74$, tibia $-4.13-4.45$, tarsomerus I $-0.08-0.10$, tarsomerus II $-0.29-0.35$, tarsomerus III -0.23 0.31 ; abdominal length $-4.22-4.90$.

Ground color brown, with central dorsum of head, venter of head and thorax yellowish brown. Central area of clypeus translucid; antenniferous tubercles and base of antennal joint I shinning; apical half of antennal joint II and joints III and IV dark brown; eyes dark red; apex of rostrum dark brown. Pronotum centrally dark brown with light median longitudinal line and sinuous lighter stripe on each side; mesopleura dark brown with dorsal margin almost black; coxae, trochanters and venter of femur yellowish brown; apex of tibia and tarsi dark brown; forewing fuscous with brown veins. Lateral margins of connexives darker than rest of abdomen, almost black.

Body covered by small black tubercles, except for central areas of venter, from head up to abdominal sternite VII. Head very long, with anterior and posterior fifths wider; clypeus narrow and conic (Fig. 1: CLY); antennal joint I slightly curved outward and dilated on apex, wider than others; antennal joints II and III progressively narrower; antennal joints II and IV wider on apex; rostrum long, surpassing eyes. Pronotum with discrete shallow rounded pits distributed on dorsum; three to five more visible pits present on propleura; acetabula with shallow median longitudinal cleft (Fig. 2: CLE); pro- and mesoacetabula with at most two weak rounded pits, one on each side of the cleft (Fig. 2: PIT); wings reaching abdominal tergite V or VI; forewing with three longitudinal veins, two extending almost to the apex of the wing, and two terminal transversal veins (the most apical can bifurcate in one end) forming three closed cells (Fig. 3: CEL); legs covered by brown setae, longer on tibiae and tarsi; trochanters with three 


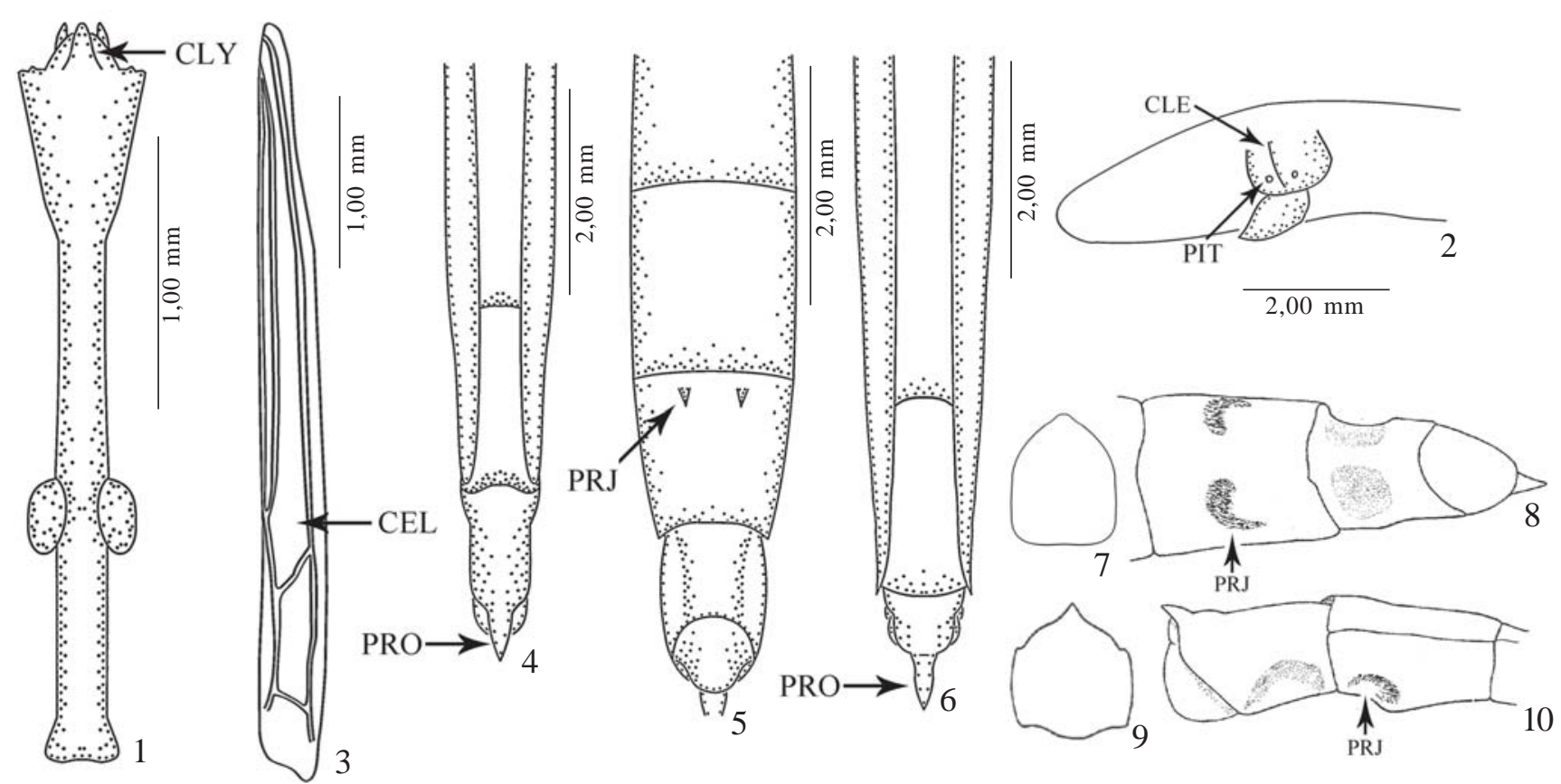

Figs. 1-10. 1-6, Hydrometra argentina Berg, 1879. 1, head, dorsal view. 2, anterior part of thorax, lateral view. 3, forewing. 4, male, apex of abdomen, dorsal view. 5, male, apex of abdomen, ventral view. 6, female, apex of abdomen, dorsal view; 7-8, Hydrometra caraiba GuérinMéneville, 1857. 7, clypeus. 8, male, apex of abdomen, ventral view (from Nieser, 1970); 9-10, Hydrometra guianana Hungerford \& Evans, 1934. 9, clypeus (from Nieser, 1970). 10, male, apex of abdomen, lateral view (from Nieser, 1970). [CEL - wing closed cell, CLE - cleft, CLY - clypeus, PIT - circular pit, PRJ - projection of male abdominal sternite VI, PRO - dorsocaudal prolongation of abdomen].

tubercles visible on dorsal view; femora with small black spines, slightly longer than body tubercles; tibiae with spines longer than that of femora and more numerous. Abdominal connexives horizontal or weakly turned up, becoming narrower up to abdominal tergite VII; abdominal tergite VIII covered by light setae, more abundant on lateral areas; abdominal tergite VIII with lateral margins curved and posterior margin prolonged in a simple sharp spine (Fig. 4: PRO); intersegmental fissures between abdominal sternites becoming fainted centrally; lateral areas of abdominal sternites with light setae; projections of abdominal sternite VI are two median spines near anterior margin (Fig. 5: PRJ).

Macropterous female. Body length-10.40-12.24; body width on pronotum $-0.41-0.54$; head length $-2.66-3.20$; head width across eyes $-0.38-0.41$; anteoculus/postoculus ratio1.93-2.00; antennal joints length (intersegmental pieces not included): I-0.39-0.43, II-0.89-1.11, III-1.82-1.96, IV0.94-1.00; minimum interocular distance-0.14-0.15; eye width $-0.14-0.15$; rostrum length beyond eyes $-0.21-0.40$; pronotum length on midline-1.34-1.60; wing length -4.10 5.20; forecoxa/midcoxa distance $-0.76-0.98$; midcoxa/hindcoxa distance-1.13-1.47; foreleg length: femur $-1.70-2.76$, tibia2.72-2.88, tarsomerus I-0.06-0.08, tarsomerus II-0.21-0.29, tarsomerus III-0.19-0.20; midleg length: femur-2.69-3.20, tibia $-2.94-3.30$, tarsomerus I $-0.06-0.08$, tarsomerus II -0.34 0.40 , tarsomerus III $-0.20-0.25$; hindleg length: femur $-3.50-4.13$, tibia $-4.16-4.51$, tarsomerus I -0.08 , tarsomerus II-0.28-0.39, tarsomerus III- $0.20-0.24$; abdominal length $-4.95-5.70$.

Very similar to males, with yellowish-brown body color and with a dorsocaudal sharp-pointed prolongation on apex of abdomen (Fig. 6: PRO). Projections of abdominal sternite VI absent.

Comments. Integrants of this species can be separated from other South American Hydrometra by the narrow coneshaped clypeus (Fig. 1: CLY); projections of male abdominal sternite VI spine-shaped (Fig. 5: PRJ); and female with a sharppointed dorsocaudal prolongation on apex of abdomen (Fig. 6: PRO). Other typical feature is the presence of circular pits on foreleg and midleg acetabula, generally one or two on each one (Fig. 2: PIT).

Distribution (Fig. 11). Widely distributed in South America (Nieser \& Melo, 1997). Distribution in Brazil: Amapá Oiapoque!; Pará - Quatipuru (Nieser, 1970), Santarém (Champion, 1898), Prainha!; Amazonas - Urucará!, Presidente Figueiredo (Pereira \& Melo, 2007), Coari (Nieser, 1970), Manaus (White, 1879), Careiro (Nieser, 1970), Itacoatiara!; Bahia! Juazeiro!; Mato Grosso - Nova Xavantina (Nieser, 1970); Mato Grosso do Sul - Corumbá (Torre-Bueno, 1926); Minas Gerais - Januária (Melo \& Nieser, 2004), Uberaba, Martinho Campos (Nieser \& Melo, 1997), Mariana (Souza et al., 2006), Parque Nacional da Serra da Canastra (Pelli et al., 2006); Rio de Janeiro - Macaé, Maricá (Ribeiro et al., in press), Rio de Janeiro (Kirkaldy, 1899)*; São Paulo! - Ubatuba!; Paraná (Jaczewski, 1928); Rio Grande do Sul - between Agudo and Nova Palma (Dona Francisca Power Plant) (Neri et al., 2005). *Kirkaldy (1899), based on material deposited on the Belgian Museum, records the species from Botafogo, without further details on 
the locality. However, it probably is the first record of the species in Rio de Janeiro State, as he indicates that the collector of the specimens was Van Volxen, who also collected in other areas in southeastern Brazil.

\section{Hydrometra caraiba Guérin-Méneville, 1857}

Hydrometra agenor Kirkaldy, 1902 [synonym determined by Drake \& Lauck (1959)]

Hydrometra championiana Torre-Bueno, 1926 [synonym determined by Drake (1954)]

Examined material. BRAZIL: Amazonas - Santo Antônio do Içá, Vila Presidente Getúlio Vargas, 04.IX.2003, (N. Hamada \& J. L. Nessimian), F. F. F. Moreira det. 2007: 1 brachypterous female (INPA) [Canini Lake, $-3,16629^{\circ} /-67,97124^{\circ}$.

Brachypterous female. Body length-19.00; body width on pronotum-0.70; head length -5.45 ; head width across eyes - 0.70; anteoculus/postoculus ratio-2.50; antennal joints length (intersegmental pieces not included): I-0.83, II-1.82, III - 6.50, IV-2.14; minimum interocular distance - 0.21 ; eye width-0.26; rostrum length beyond eyes_rotrum does not surpasses eyes; pronotum length on midline-2.69; wing length-2.55; forecoxa/midcoxa distance-1.44; midcoxa/ hindcoxa distance - 2.69; foreleg length: femur - 5.60, tibia5.68 , tarsomerus I- 0.10 , tarsomerus II -0.48 , tarsomerus III0.31; midleg length: femur-6.72, tibia-6.32, tarsomerus I0.13 , tarsomerus II -0.75 , tarsomerus III -0.39 ; hindleg length: femur -8.72 , tibia -8.24 , tarsomerus I-0.13, tarsomerus II0.64, tarsomerus III-0.38; abdominal length-7.20.

Comments. Hungerford \& Evans (1934) state in their identification key that body length of females of this species is superior to $22 \mathrm{~mm}$ (as in original description), although other data from literature point out smaller values (e.g. Champion, 1898). Furthermore, Drake \& Lauck (1959) believed that the measures given given in the original description were due to typographical errors, and delimit a normal variation between 16 and $18 \mathrm{~mm}$.

Hydrometra caraiba is very similar to $H$. guianana, but can be separated from it mainly by the shape of clypeus (Fig. 7) and by position and shape of the projections of sternite VI of male (Fig. 8: PRJ). The apex of female abdomen of the two species is also very similar.

Distribution (Fig. 12). The species is known from Mexico to Peru (Nieser, 1970). Distribution in Brazil: Amazonas Tabatinga, Tefé/Coari (Catuá Lake) (NIESER, 1970), Santo Antônio do Içá (Torre-Bueno, 1926*), Manacapuru (Hungerford \& Evans, 1934). *Cited as Río Putumayo, Brasil. The Putumayo River is called Içá River when it crosses from Colombia into Brazil, and runs through the municipality of Santo Antônio do Içá until it reaches the Amazon River.

\section{Hydrometra guianana Hungerford \& Evans, 1934}

Examined material. BRASIL: Amazonas - Presidente Figueiredo, Balbina, igarapé Trilha do Boto, Ramal da Morena [02 07' 02,0" S /
59 18 ' 24,4" W], 12.X.2002, (D. L. V. Pereira): 1 macropterous female. Manaus, Reserva Ecológica Adolpho Ducke, 30.IV.1990, (M. V. B. Garcia): 1 brachypterous female.
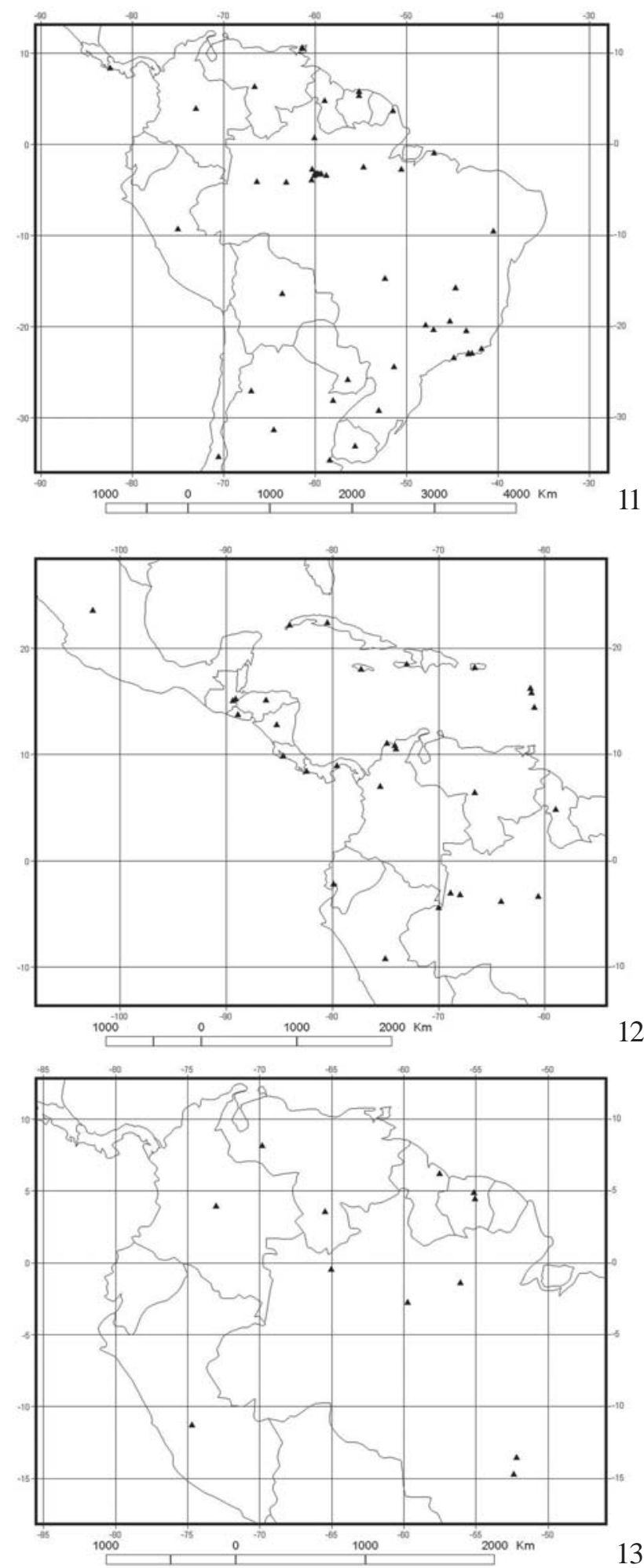

Figs. 11-13. 11, geographic distribution of Hydrometra argentina Berg, 1879. 12, geographic distribution of Hydrometra caraiba GuérinMéneville, 1857. 13, geographic distribution of Hydrometra guianana Hungerford \& Evans, 1934. 
Brachypterous female. Body length-15.04; body width on pronotum-0.61; head length-5.15; head width across eyes- 0.45 ; anteoculus/postoculus ratio-3.17; antennal joints length (intersegmental pieces not included): I -0.54 , II -1.75 , III-6.08, IV-2.60; minimum interocular distance- 0.16 ; eye width-0.26; rostrum length beyond eyes-rotrum does not surpasses eyes; pronotum length on midline-2.45; wing length -6.64; forecoxa/midcoxa distance -1.40 ; midcoxa/ hindcoxa distance -2.30 ; foreleg length: femur -5.25 , tibia5.55 , tarsomerus I- 0.10 , tarsomerus II -0.48 , tarsomerus III0.33 ; midleg length: femur -6.32 , tibia -6.08 , tarsomerus I0.11 , tarsomerus II -0.64 , tarsomerus III -0.38 ; hindleg length: femur -7.84 , tibia -7.60 , tarsomerus I- 0.10 , tarsomerus II0.54 , tarsomerus III -0.29 ; abdominal length -5.85 .

Macropterous female. Body length -16.48 ; body width on pronotum -0.74 ; head length -5.25 ; head width across eyes0.68 ; anteoculus/postoculus ratio-2.77; antennae broken off; minimum interocular distance -0.16 ; eye width -0.26 ; rostrum length beyond eyes-rotrum does not surpasses eyes; pronotum length on midline-2.15; wing length-2.45; forecoxa/midcoxa distance-1.25; midcoxa/hindcoxa distance-2.25; foreleg length: femur-4.40, tibiae and tarsi broken off; midleg length: femur -5.36 , tibia- 5.12 , tarsomerus I -0.08 , tarsomerus II -0.60 , tarsomerus III -0.31 ; hindleg length: femur -6.48 , tibia -5.76 , tarsomerus $\mathrm{I}-0.09$, tarsomerus II -0.45 , tarsomerus III -0.28 ; abdominal length5.75 .

Comments. Specimens of Hydrometra guianana can be identified by the broad clypeus with a small angulose median projection (Fig. 9), and by projections of abdominal sternite VI of male U-shaped and turned to the terminal part of the body, covered by a dense layer of setae and located on the posterior half of the segment (Fig. 10: PRJ).

According to Hungerford \& Evans (1934) and Nieser (1970), body length of male can range from 14.3 to $16.0 \mathrm{~mm}$, whereas in females it ranges from 15.0 to $18.4 \mathrm{~mm}$. Brachypterous individuals are generally longer than macropterous (Nieser 1970).

Distribution (Fig. 13). The species is well distributed in Northern South America (Nieser 1970). Distribution in Brazil: Pará -Paru do Oeste River; Amazonas - Santa Isabel do Rio Negro (Nieser 1970), Presidente Figueiredo!, Estrada Manaus/ Rio Preto da Eva (km 77-78) (Nieser 1970), Manaus!; Mato Grosso - source region of Xingu River (Garapu Lake); Serra do Roncador (Nieser 1970).

Acknowledgements. This study was supported by Programa PróVárzea (IBAMA), through the project "Bases Científicas para Conservação da Várzea", by Fadesp and by CNPq.

\section{REFERENCES}

Andersen, N. M. 1977. A new and primitive genus and species of Hydrometridae (Hemiptera, Gerromorpha) with a cladistic analysis of relationships within the family. Entomologica Scandinavica 8: $301-316$.

Champion, G. C. 1898. Hemiptera - Heteroptera. Biologia CentraliAmericana. Rhynchota 2: 1-416.

Drake, C. J. 1953. Synonymical data and description of a new Hydrometra (Hemiptera: Hydrometridae). Journal of the Kansas Entomological Society 26: 40-41.

Drake, C. J. 1954. Synonymical data: descriptions of new Hydrometridae (Hemiptera). The Great Basin Naturalist 14: 61-66.

Drake, C. J. \& D. R. Lauck. 1959. Descriptions, synonymy, and checklist of American Hydrometridae (Hemiptera: Heteroptera). The Great Basin Naturalist 19: 43-52.

Goulding, M.; R. B. Barthem \& E. J. G. Ferreira. 2003. The Smithsonian Atlas of the Amazon. Washington. Smithsonian Institution. $253 \mathrm{p}$.

Hungerford, H. B. \& N. E. Evans. 1934. The Hydrometridae of the Hungarian National Museum and others studies in the family (Hemiptera). Annales Musei Nationalis Hungarici 28: $32-$ 112.

Jaczewski, T. 1928. Hydrometridae from the State of Paraná. Annales Musei Zoologici Polonici 7: 81-84, prancha VII.

Kirkaldy, G. W. 1899. Aquatic Rhynchota in the collection of the Royal Museum of Belgium. Annales de la Société Entomologique de Belgique 1899: 505-510.

Melo, A. L. \& N. Nieser. 2004. Faunistical notes on aquatic Heteroptera of Minas Gerais (Brazil): an annotated list of Gerromorpha and Nepomorpha collected near Januária, MG. Lundiana 5: 43-49.

Neri, D. B.; C. B. Kotzian \& A. E. Siegloch. 2005. Composição de Heteroptera aquáticos e semi-aquáticos na área de abrangência da U.H.E. Dona Francisca, RS, Brasil: fase de pré-enchimento. Iheringia. Série Zoologia 95: 421-429.

Nessimian, J. L.; N.Hamada; N. Ferreira-Jr, \& P. De Marco-Jr. 2004. Sub-estudo Entomofauna Aquática - Bases científicas para a conservação da várzea: Identificação e caracterização de regiões biogeográficas. PROVÁRZEA/IBAMA, Relatório Técnico.

Nieser, N. 1970. Hydrometridae of the Suriname and the Amazon, with additional records of other Neotropical species (Hemiptera Heteroptera). Studies on the Fauna of Suriname and other Guyanas 12: 139-151.

Nieser, N. \& A. L. Melo. 1997. Os Heterópteros Aquáticos de Minas Gerais. Guia Introdutório com Chave de Identificação para as Espécies de Nepomorpha e Gerromorpha. Belo Horizonte. Editora UFMG. 180 p.

Pelli, A.; N. Nieser \& A. L. Melo. 2006. Nepomorpha and Gerromorpha (Insecta: Heteroptera) from the Serra da Canastra, southwestern Minas Gerais state, Brazil. Lundiana 7: 67-72.

Pereira, D. L. V. \& A. L. Melo. 2007. Aquatic and semiaquatic Heteroptera (Insecta) from Pitinga, Amazonas, Brazil. Acta Amazonica 37: 643-648.

Polhemus, J. T.; D. A. Polhemus. 2008. Global diversity of true bugs (Heteroptera; Insecta) in freshwater. Hydrobiologia 595: 379391.

Ribeiro, J. R. I.; V. P.Alecrim; F. F. F. Moreira; J. F. Barbosa \& J. L. Nessimian. Espécies de heterópteros dulçaquícolas (Hemiptera, Heteroptera, Gerromorpha e Nepomorpha) registradas no Estado do Rio de Janeiro, Brasil. Arquivos do Museu Nacional, in press.

Souza, M. A. A.; A. L. Melo \& G. J. C. Vianna. 2006. Heterópteros aquáticos oriundos do Município de Mariana, MG. Neotropical Entomology 35: 803-810.

Torre-Bueno, J. R. 1926. The family Hydrometridae in the western hemisphere. Entomologica Americana [new series] 7: 83-128.

White, F. B., 1879. List of the Hemiptera collected in the Amazons by Prof. J. W. H. Trail, M. A., M. D., in the years 1873-1875, with descriptions of the new species. Transactions of the Royal Entomological Society of London 4: 267-276. 